www.jmscr.igmpublication.org

Index Copernicus Value: 79.54

ISSN (e)-2347-176x ISSN (p) 2455-0450

crossref DOI: https://dx.doi.org/10.18535/jmscr/v7i6.17

\title{
Retinopathy and its associated factors in Type 2 Diabetes Mellitus in rural population of central India
}

\author{
Authors \\ Manoj Kumar ${ }^{1}$, Ramakant Rawat ${ }^{2 *}$, Pankaj Kashyap ${ }^{3}$, Udit Gupta ${ }^{4}$ \\ ${ }^{1}$ Professor \& Head, Dept of Medicine, UP University of Medical Sciences (UPUMS), Saifai, Etawah (UP) \\ ${ }^{2}$ Associate Professor, Dept of Medicine, UP University of Medical Sciences (UPUMS), Saifai, Etawah (UP) \\ ${ }^{3,4} \mathrm{PG}$ Junior Resident, Dept of Medicine, UP University of Medical Sciences (UPUMS), Saifai, Etawah (UP) \\ *Corresponding Author \\ Dr Ramakant Rawat \\ Associate Prof, Dept, Medicine, UPUMS, Saifai, Etawah (UP) - 206130, India
}

\begin{abstract}
Introduction: Diabetes is traditionally known as a "silent disease," exhibiting no symptoms until it progresses to severe target organ damage. Duration of diabetes is closely associated with onset and severity of diabetic retinopathy. Lack of glycaemic control, hypertension, renal disease manifested in form of microalbuminuria and proteinuria, elevated level of serum lipid are associated with extravasated lipid in retina (hard exudates) and visual loss., pregnancy and tobacco use.

Aim: To study retinopathy and its associated factors in type 2 Diabetes Mellitus in the rural population of central India.

Material \& Methods: 315 diagnosed Type 2 diabetes mellitus patients who fulfilled the inclusion and exclusion criteria were selected from health camp from rural areas around the U.P.U.M.S in the neighbouring districts of Etawah and Mainpuri. The patients were recruited after written consent. The information was collected using structured questionnaire and physical examination. HbAlc was measured using immune turbiditric method. All participants underwent a comprehensive dilated fundus examination to detect diabetic retionopathy by indirect ophthalmoscopy. Diabetic Retinopathy was clinically graded in accordance with the International Clinical Diabetic Retinopathy guidelines.

Results: A sample of 315 patients revealed that $39 \%$ were below 50years. Mean age of study population was 51.72 yrs. Average duration of diabetes was 3.97 years. Mean BMI was $25.23 \mathrm{~kg} / \mathrm{m}^{2}$. Mean FBS was 193.74 $\mathrm{mg} / \mathrm{dl}$. Average PPBS was $322.85 \mathrm{mg} / \mathrm{dl}$. Average HBAlc was 9.07\%. Mean total cholesterol was 182.78 $\mathrm{mg} / \mathrm{dl}$, HDL was $43.37 \mathrm{mg} / \mathrm{dl}$, LDL was $105.30 \mathrm{mg} / \mathrm{dl}$, and Triglyceride was $170.50 \mathrm{mg} / \mathrm{dl}$. Socio economic status revealed $76 \%$ belonged to Lower and Lower middle class. The prevalence of NPDR was seen to be $19 \%$ and PDR 1.9\%. Age and increased BP showed significant association with retinopathy with $p$ value of $<0.001$ and 0.003 respectively.
\end{abstract}

Conclusion: Duration of Diabetes and Blood pressure were strongly associated with Diabetic retinopathy

Keywords: Diabetes Mellitus, Retinopathy, Glycemic Control, Hypertension.

\section{Introduction}

Diabetes mellitus (DM) refers to a group of common metabolic disorders that share the phenotype of hyperglycaemia with disturbances of carbohydrate, fat and protein metabolism resulting from defects in insulin secretion, insulin action, or both. ${ }^{1} \mathrm{DM}$ is classified on the basis of the 
pathogenic process that leads to hyperglycaemia, as opposed to earlier criteria such as age of onset or type of therapy. The two broad categories of DM are designated as type 1 and type 2 . Both types of diabetes are preceded by a phase of abnormal glucose homeostasis as the pathogenic processes progress. Type $1 \mathrm{DM}$ is the result of complete or near-total insulin deficiency. Type $2 \mathrm{DM}$ is a heterogeneous group of disorders characterized by variable degrees of insulin resistance, impaired insulin secretion, and increased glucose production4. Diabetic Retinopathy (DR) is one of the common complication of diabetes mellitus and the leading cause of blindness worldwide. ${ }^{2}$ It is characterized by signs of retinal ischemia and/or increased retinal vascular permeability, with loss of vision due to neo-vascularization, haemorrhage, retinal detachment, macular oedema and/or retinal capillary non-perfusion. ${ }^{3}$ Patients with DR are 25 times more likely to become blind than those without diabetes. In patients with type 2 diabetes, approximately $20 \%$ have retinopathy at the time of diabetes diagnosis \&approximately $25 \%$ of patients with type 1 diabetes have retinopathy after 5 years, with this figure increasing to $60 \%$ and $80 \%$ after 10 and 15 years, respectively. ${ }^{4}$ This condition is of vascular origin, and is characterized by signs of retinal ischemia as well as signs of increased vascular permeability. ${ }^{5}$ It is a well-known fact that retinopathy often goes unnoticed until vision loss occurs, hence early detection, timely treatment and appropriate care can protect or delay the vision loss. ${ }^{6}$ This study was conducted to investigate the associations between the diabetic retinopathy and a variety of risk factors, including duration of diabetes, HbA1c levels, hypertension, age, gender and dyslipidaemia.

\section{Material and Method}

315 patients of age more than 25 years with type 2 DM out of which 158 were male and 157 were female participated in the study. All secondary causes of hyperglycemia and type $1 \mathrm{DM}$ were excluded from the study. All consecutive patients were recruited (during their routine follow-up) in the Department of Internal Medicine U.P.U.M.S Saifai Etawah during the time period Jan 2017 to June 2018. Diabetes was defined on fulfillment of criteria laid down by the WHO Consultation Group Report and International diabetes federation IDF, i.e., plasma fasting blood glucose $\geq 126 \mathrm{mg} / \mathrm{dl}$ or $2 \mathrm{~h}$ plasma post-glucose value $\geq 200 \mathrm{mg} / \mathrm{dl}$ OR HbAlc $>$ $6.5 \%$ and known cases of type 2 diabetes mellitus. $\mathrm{HbA1c}$ has now been recommended by an International Committee and by the ADA as a means to diagnose diabetes. The participants diagnosed as Diabetics were then asked to follow up in our institute for further evaluation. History regarding drug usage and family history of diabetes were taken. Blood samples were drawn for measurement of $\mathrm{HbA1c}$, lipid profile, complete blood count and kidney function tests. All biochemical test were done using an autoanalyser. $\mathrm{HbA1c}$ was measured using immune turbiditric method. All participants underwent a comprehensive dilated fundus examination to detect DR by indirect ophthalmoscopy. DR was clinically graded in accordance with the International Clinical Diabetic Retinopathy guidelines.

\begin{tabular}{|l|l|}
\hline $\begin{array}{l}\text { Disease Severity } \\
\text { Level }\end{array}$ & \multicolumn{1}{c|}{$\begin{array}{l}\text { Findings Observable upon } \\
\text { Dilated Ophthalmoscopy }\end{array}$} \\
\hline $\begin{array}{l}\text { No apparent } \\
\text { retinopathy }\end{array}$ & No abnormalities \\
\hline Mild NPDR & Micro aneurysms only \\
\hline Moderate NPDR & $\begin{array}{l}\text { More than just micro aneurysms } \\
\text { but less than severe NPDR }\end{array}$ \\
\hline Severe NPDR & $\begin{array}{l}\text { Any of the following and no signs } \\
\text { of proliferative retinopathy: } \\
\text { - More than 20 intraretinal } \\
\text { International } \\
\text { Definition }\end{array}$ \\
& $\begin{array}{l}\text { hemorrhages in each of four } \\
\text { quadrants } \\
\text { Definite venous beading in two } \\
\text { or more quadrants } \\
\text { Prominent IRMA in one or more } \\
\text { quadrants }\end{array}$ \\
\hline PDR & $\begin{array}{l}\text { One or both of the following: } \\
\text { Neovascularization } \\
\text { Vitreous/preretinal hemorrhage }\end{array}$ \\
\hline
\end{tabular}

IRMA = intraretinal microvascular abnormalities; NPDR = nonproliferative diabetic retinopathy; $\mathrm{PDR}=$ proliferative diabetic retinopathy

Note: Any patient with two or more of the characteristics of severe NPDR is considered to have very severe NPDR 


\section{Statistical Analysis}

The data was coded and analysed using Microsoft Excel and SPSS 23. The results are presented in frequencies, percentages and mean $\pm S D$. The Chisquare test was used to compare categorical variables. The one way analysis of variance (ANOVA) and Unpaired t-test was used to compare continuous variables. The p-value $<0.05$ was considered significant.

\section{Results}

The present study is cross sectional observational study, conducted in the Department of General Medicine of UPUMS Saifai, Etawah from January 2017 to June 2018 with the objective to determine the retinopathy and its associated factors in Type 2 DM in rural population of central India.

A total of 315 Type 2 Diabetic cases were included in this study. Out of which 158 were male and 157 were female and we studied retinopathic changes in them.

In this study patients who were having Type 2 Diabetes mellitus and of more than 25 years age were included, out of which 123 (39\%) were below 50years and 123 (39\%) were between 51-60 years and $55(17.5 \%)$ were between 61-70 years and 14 (4.4\%) were in $>70$ years of age group.

Mean age of study population was $51.72 \mathrm{yrs}$. Average duration of diabetes was 3.97 years.

Mean BMI was $25.23 \mathrm{~kg} / \mathrm{m}^{2}$. Mean FBS was 193.74 $\mathrm{mg} / \mathrm{dl}$. Average PPBS was $322.85 \mathrm{mg} / \mathrm{dl}$. Average HBA1c was $9.07 \%$.

Mean total cholesterol was $182.78 \mathrm{mg} / \mathrm{dl}$, HDL was $43.37 \mathrm{mg} / \mathrm{dl}$, LDL was $105.30 \mathrm{mg} / \mathrm{dl}$, and Triglyceride was $170.50 \mathrm{mg} / \mathrm{dl}$. The prevalence of diabetic retinopathy was observed to be $21 \%$, which constituted $19 \%$ of Non-proliferative diabetic retinopathy.
Table 1 Mean Age, duration, anthropomorphic, blood sugar, lipid profile

\begin{tabular}{|c|c|c|c|}
\hline \multirow[b]{2}{*}{ Characteristics } & \multicolumn{2}{|c|}{ Sex } & \multirow[t]{2}{*}{ Total } \\
\hline & Males & Females & \\
\hline Age & $\begin{array}{l}51.62 \pm \\
12.3\end{array}$ & $\begin{array}{c}51.83 \pm \\
11.74\end{array}$ & $51.72 \pm 12.36$ \\
\hline $\begin{array}{c}\text { Duration of } \\
\text { diabetes (in years) }\end{array}$ & $4.59 \pm 2.3$ & $3.33 \pm 1.69$ & $3.97 \pm 2.5$ \\
\hline BMI & $\begin{array}{l}25.27 \pm \\
4.08\end{array}$ & $\begin{array}{c}25.19 \pm \\
4.40\end{array}$ & $25.23 \pm 4.2$ \\
\hline FBS & $\begin{array}{c}196.63 \pm \\
77.79\end{array}$ & $\begin{array}{c}190.84 \pm \\
61.321\end{array}$ & $193.74 \pm 70.02$ \\
\hline PPBS & $\begin{array}{l}323.70 \pm \\
97.06\end{array}$ & $\begin{array}{l}322.01 \pm \\
98.90\end{array}$ & $322.85 \pm 97.86$ \\
\hline HBA1C & $9.16 \pm 2.1$ & $8.98 \pm 2.2$ & $9.07 \pm 2.15$ \\
\hline Total Cholesterol & $\begin{array}{c}182.08 \pm \\
47.42\end{array}$ & $\begin{array}{c}183.49 \pm \\
41.07\end{array}$ & $182.78 \pm 44.3$ \\
\hline HDL & $\begin{array}{l}42.23 \pm \\
7.48\end{array}$ & $\begin{array}{l}44.53 \pm \\
7.88\end{array}$ & $43.37 \pm 7.75$ \\
\hline LDL & $\begin{array}{c}104.98 \pm \\
33.49\end{array}$ & $\begin{array}{c}105.63 \pm \\
32.08\end{array}$ & $105.30 \pm 32.74$ \\
\hline TG & $\begin{array}{c}174.33 \pm \\
94.22\end{array}$ & $\begin{array}{c}166.64 \pm \\
70.05\end{array}$ & $170.50 \pm 83.01$ \\
\hline
\end{tabular}

Table 1 reveals the gender wise distribution of demographic and clinical profile of study subjects. Average age of duration of diabetes was more among males diabetic patients. Females study subjects showed increased average levels of lipid profile, except triglyceride.

Table 2 Socio Economic Status of Diabetics

\begin{tabular}{|c|c|c|}
\hline $\begin{array}{c}\text { Socio economic } \\
\text { Class }\end{array}$ & NO. of diabetic & Percent \\
\hline Lower & 167 & 53.0 \\
\hline Lower Middle & 75 & 23.8 \\
\hline Middle & 34 & 10.8 \\
\hline Upper Middle & 24 & 7.6 \\
\hline Upper & 15 & 4.8 \\
\hline
\end{tabular}

Table 2- Most of the study subjects belonged to lower and lower middle class of economic status.

Table 3: Association of retinopathy with duration of diabetes

\begin{tabular}{|c|c|c|c|c|c|c|c|c|}
\hline \multirow{2}{*}{$\begin{array}{c}\text { Duration } \\
\text { of } \\
\text { diabetes }\end{array}$} & \multicolumn{2}{|c|}{$\begin{array}{c}\text { No. of } \\
\text { patients }\end{array}$} & \multicolumn{2}{|c|}{ NPDR } & \multicolumn{2}{c|}{ PDR } & \multicolumn{2}{|c|}{ No } \\
\cline { 2 - 9 } & No. & $\%$ & No. & $\%$ & No. & $\%$ & No. & $\%$ \\
\hline <5 years & 101 & 32.1 & 10 & 9.9 & 0 & 0.0 & 91 & 90.1 \\
\hline 5-10 years & 70 & 22.2 & 16 & 22.9 & 4 & 5.7 & 50 & 71.4 \\
\hline$>10$ years & 31 & 9.8 & 22 & 71.0 & 0 & 0.0 & 9 & 29.0 \\
\hline $\begin{array}{c}\text { New } \\
\text { cases }\end{array}$ & 113 & 35.9 & 12 & 10.6 & 2 & 1.8 & 99 & 87.6 \\
\hline
\end{tabular}


Table 3 The duration of diabetes was $<5$ years among $32.1 \%$ patients. The prevalence of NPDR was higher among patients whom duration of diabetes was $>10$ years $(71 \%)$ as compared to other duration of diabetes. The prevalence of PDR was higher among patients who whom duration of diabetes was 5-10 years (5.7\%).

Table 4: Association of retinopathy with age and sex

\begin{tabular}{|l|c|c|c|c|c|c|c|c|c|}
\hline $\begin{array}{l}\text { Age in } \\
\text { years }\end{array}$ & \multirow{2}{*}{ No. } & \multirow{2}{*}{$\%$} & \multicolumn{2}{|c|}{ NPDR } & \multicolumn{2}{|c|}{ PDR } & \multicolumn{2}{|c|}{ No } & \\
\cline { 1 - 7 } & & & & & & & & & \\
\hline$<50$ & 123 & 39.0 & 4 & 3.3 & 2 & 1.6 & 117 & 95.1 & \multirow{2}{*}{$0.0001^{*}$} \\
\hline $51-60$ & 123 & 39.0 & 34 & 27.6 & 2 & 1.6 & 87 & 70.7 & \\
\hline $61-70$ & 55 & 17.5 & 10 & 18.2 & 2 & 3.6 & 43 & 78.2 & \\
\hline$>70$ & 14 & 4.4 & 12 & 85.7 & 0 & 0.0 & 2 & 14.3 & \\
\cline { 1 - 6 } Sex & & & & & & & & & \multirow{2}{*}{0.61} \\
\hline Male & 158 & 50.2 & 28 & 17.7 & 4 & 2.5 & 126 & 79.7 & \\
\hline Female & 157 & 49.8 & 32 & 20.4 & 2 & 1.3 & 123 & 78.3 & \\
\hline
\end{tabular}

Table 4 shows the increased proportion of diabetic retinopathy with increase in age of the study subjects among both proliferative and nonproliferative diabetic retinopathy and this association was found to be statistically significant ( $p$ value - 0.0001). The prevalence of diabetic retinopathy was nearly same among both the genders.

Table 5: Association of retinopathy with hypertension

\begin{tabular}{|c|c|c|c|c|c|c|c|c|c|}
\hline \multirow[t]{2}{*}{ Hypertension } & \multicolumn{2}{|c|}{$\mathrm{N}_{0}$. of patients } & \multicolumn{2}{|c|}{ NPD R } & \multicolumn{2}{|c|}{ P D R } & \multicolumn{2}{|c|}{$\mathbf{N} \quad \mathbf{0}$} & \multirow[t]{2}{*}{$p$-value ${ }^{1}$} \\
\hline & No. & $\%$ & $\mathrm{~N}_{0}$. & $\%$ & $\mathrm{~N}_{0}$. & $\%$ & $\mathrm{~N}_{0}$. & $\%$ & \\
\hline & 86 & 27.3 & 24 & 27.9 & 4 & 4.7 & 58 & 67.4 & $0.003^{*}$ \\
\hline $\mathrm{Abs}$ e n t & 229 & 72.7 & 36 & 15.7 & 2 & 0.9 & 191 & 83.4 & \\
\hline
\end{tabular}

Table 5 shows the association of retinopathy with hypertension. Hypertension was seen among majority (27.3) patients. The prevalence of NPDR was higher among patients of hypertensive (27.9\%) than non-hypertensive $(15.7 \%)$. The prevalence of PDR was $4.7 \%$ who were hypertensive. There was significant $(\mathrm{p}=0.003)$ association of retinopathy with hypertension.
Table 6: Comparison of anthropometric parameters with retinopathy

\begin{tabular}{|l|l|l|l|l|}
\hline $\begin{array}{l}\text { Anthropometr } \\
\text { ic parameters }\end{array}$ & NPDR & PDR & No & $\begin{array}{l}\text { p- } \\
\text { value } \\
\mathbf{1}\end{array}$ \\
\hline BMI & $\begin{array}{l}25.71 \pm 3.6 \\
4\end{array}$ & $27.96 \pm 3.59$ & $25.10 \pm 4.38$ & 0.17 \\
\hline $\begin{array}{l}\text { Waist } \\
\text { circumference }\end{array}$ & $\begin{array}{l}85.93 \pm 9.9 \\
\text { Hip } \\
\text { circumference }\end{array}$ & $\begin{array}{l}91.33 \pm 10.8 \\
2\end{array}$ & $\begin{array}{l}81.25 \pm 15.4 \\
1\end{array}$ & 0.06 \\
\hline WHR & $0.91 \pm 0.03$ & $0.92 \pm 0.01$ & $0.90 \pm 0.04$ & 0.22 \\
\hline
\end{tabular}

Table-6 shows the comparison of anthropometric parameters with retinopathy. There was no significant $(p>0.05)$ difference in anthropometric parameters with retinopathy.

Table 7: Comparison of lipid profile and retinopathy

\begin{tabular}{|l|c|c|c|c|}
\hline & $\begin{array}{c}\text { NPDR } \\
(M e a n \pm S D)\end{array}$ & $\begin{array}{c}\text { PDR } \\
(\text { Mean } \pm \text { SD })\end{array}$ & $\begin{array}{c}\text { No DR } \\
(\text { Mean } \pm \text { SD })\end{array}$ & $\begin{array}{c}\text { P } \\
\text { value }\end{array}$ \\
\hline FBS & $198.40 \pm 64.45$ & $246.00 \pm 143.64$ & $191.36 \pm 68.74$ & 0.14 \\
\hline HbA1c & $8.55 \pm 1.81$ & $10.23 \pm 3.95$ & $9.17 \pm 2.15$ & 0.06 \\
\hline HDL & $43.47 \pm 8.07$ & $45.07 \pm 7.30$ & $43.31 \pm 7.71$ & 0.85 \\
\hline TG & $191.35 \pm 91.38$ & $211.33 \pm 7.23$ & $164.49 \pm 80.97$ & 0.06 \\
\hline & & & & \\
\hline
\end{tabular}

Table-7 shows the comparison of blood glucose and lipid profile with retinopathy. All the parameters were observed to be increased among proliferative diabetic retinopathy patients compared to other study subjects. But the difference was not sufficient to be proven a statistically significant difference. $(\mathrm{p}$ value $>0.05$ )

\section{Discussion}

Retinopathy was detected in $22.86 \%$ diabetics in our study. Non proliferative retinopathy was most common variety of retinopathy (20.95\%). Most common abnormality was micro-aneurysm. These findings are similar to study by Ramachandran A et $\mathrm{al}^{7}$ who found retinopathy in $23.7 \%$ (background retinopathy in $20.0 \%$ and proliferative in $3.7 \%$ ).in study by Rema M et $\mathrm{al}^{8}$ (2006) $34.1 \%$ had evidence of retinopathy. This included $30.8 \%$ with nonproliferative diabetic retinopathy including $6.4 \%$ with maculopathy and $3.4 \%$ with proliferative diabetic retinopathy. In a study conducted by Dandona L et al. ${ }^{9}$ diabetic retinopathy was present in $22.3 \%$. Most of the diabetic retinopathy was of the mild $(50 \%)$ or moderate $(39.3 \%)$ nonproliferative type. In a study by $\mathrm{V}$ Narenderan et 
$\mathrm{al}^{10}, 26.2 \%$ self-reported history diabetics had retinopathy. Non-proliferative diabetic retinopathy (94.1\%) was the most common form of retinopathy seen. Higher prevalence of Retinopathy was seen in study by Mohan $\mathrm{V}$ et $\mathrm{al}^{11}$ in which Retinopathy was detected in $52.0 \%$ of patients which included $41.7 \%$ with non-proliferative and $10.3 \%$ with proliferative diabetic retinopathy but it was a institute based study in a urban area . Lower prevalence was seen in Chennai Urban Rural Epidemiology Study (CURES) $^{12}$ in which the overall prevalence of diabetic retinopathy was $17.6 \%$. Raman $\mathrm{R}$ et $\mathrm{al}^{13}$ in a study found the prevalence of diabetic retinopathy as $10.3 \%$ in the rural Indian population. A study conducted by Vaz NC et al. ${ }^{14}$ found the prevalence of diabetic retinopathy to be $15.4 \%$. In a study conducted by Jonas JB et al ${ }^{15}$ diabetic retinopathy prevalence was $9.6 \%$.

\section{Conclusion}

Retinopathy was detected in $20.95 \%$ Diabetics. Non proliferative retinopathy was most common variety of retinopathy (19.04\%). There was positive correlation between duration of diabetes, age and hypertension with diabetic retinopathy while no significant association was found between gender, anthroprometric measurements and de-arranged fasting lipid profile.

\section{References}

1. World Health Organization. Definition, Diagnosis and Classification of Diabetes Mellitus and its Complications. Part 1: Diagnosis and Classification of Diabetes Mellitus.1999; 2:3-8.

2. World Health Organization. WHO Expert Committee on Diabetes Mellitus: second report. World Health Organ Tech Rep Ser1980; 646:1-80.

3. Bamashmus MA, Gunaid AA, Khandekar RB: Diabetic retinopathy, visual impairment and ocular status among patients with diabetes mellitus I Yemen: a hospital-based study. Indian J Ophthalmol2009, 57:293298.
4. Klein R. Klein BE. Moss SE. et al. The Wisconsin Epidemiologic Study of Diabetic Retinopathy: II. Prevalence and risk of diabetic retinopathy when age at diagnosis is less than 30 years. Arch Ophthalmol 1984; 102: 520536.

5. Jammal H, Khader Y, Alkhatib S, Abujbara M, Alomari M, Ajlouni K. Diabetic retinopathy in patients with newly diagnosed type 2 diabetes mellitus in Jordan: prevalence and associated factors. J Diabetes 2013; 5:172-9.

6. Looker H.C, Nyangoma S.O, Cromie D, Olson JA, Leese GP, Black M et al. Diabetic retinopathy at diagnosis of type 2 diabetes in Scotland. Diabetologia 2013; 55:2335-42.

7. .Ramachandran A, Snehalatha C, Satyavani K, Latha E, Sasikala R, Vijay V. Prevalence of vascular complications and their risk factors in type 2 diabetes. J Assoc Physicians India. 1999;47:1152-6.

8. Rema M, Ponnaiya M, Mohan V. Prevalence of retinopathy in non-insulin dependent diabetes mellitus in southern India. Diabetes Res Clin Practice. 1996;24:29-36.

9. Dandona L, Dandona R, Naduvilath TJ, McCarty CA, Rao GN. Population based assessment of diabetic retinopathy in an urban population in southern India. $\mathrm{Br} \mathrm{J}$ Ophthalmol. 1999;83:937-40.

10. Narendran V, John RK, Raghuram A, Ravindran RD, Nirmalan PK, Thulasiraj RD. Diabetic retinopathy among self reported diabetics in southern India: a population based assessment. $\mathrm{Br} \mathrm{J}$ Ophthalmol. 2002;86:1014-8.

11. Mohan V, Premalatha G, Sastry NG. Ischaemic heart disease in south Indian NIDDM patients - A clinic based study on 6597 NIDDM patients. Int J Diab Developing Countries. 1995;15:64-7.

12 .Rema M, Premkumar S, Anitha B, Deepa R, Pradeepa R, Mohan V. Prevalence of Diabetic Retinopathy in Urban India: The Chennai Urban Rural Epidemiology Study 
(CURES) Eye Study- I. Invest Ophthalmol Vis Sci. 2005; 46:2328-33.

13 Raman R, Ganesan S, Pal SS, Kulothungan V, Sharma T. Prevalence and risk factors for diabetic retinopathy in rural India. Sankara Nethralaya Diabetic Retinopathy Epidemiology

14 Vaz NC, Ferreira AM, Kulkarni MS, Vaz FS. Prevalence of diabetes mellitus in a rural population of Goa, India. Natl Med J India. 2011 Jan-Feb; 24(1):16-8.

15 Jonas JB, Nangia V, Joshi PP, Matin A, Panda-Jonas S. Diabetes mellitus in rural India. Epidemiology. 2010; 21(5):754-5. 